\title{
ISLAM AS A MULTIDIMENSIONAL POTENTIAL FOR CRISIS?
}

\author{
ANDREA K. RIEMER
}

The end of the bipolar system of power with relatively clear structures and few agents within the international system resulted in wide ranging discussions of the term 'security'. There was an unspoken agreement of the necessity to broaden the term. New situations arose, old ones declined in importance.

Religious concepts have always been an essential trigger for societal development, but were only rarely seen under the 'umbrella of security'. Religious movements have been used for political purpose in a manifold sense. They were a means to push the development of society and they have also been obstacles to progress. We know that religion is an essential part in societal development (e.g. in the pre-phase of transformation in Central Europe or in all countries with Islamic predominance).

Islam plays a special role in the context of current discussion over the meaning of security. From the very beginning it has been a political concept and a religious movement, which covers a large number of societal issues. A lot of misunderstandings and misinterpretations especially in the Western World have made this religious concept more a myth, a constructed threat and a potential for crisis. Only a few limited sources can be found to help to understand this development. 
The article will therefore try to answer the question as to whether a religious concept which is strongly politicised - like Islam - can be a potential for crisis. When we speak of 'potential for crisis', we refer to a constellation of situation which might lead to a crisis in the understanding of a crucial change (either positive or negative these are subjective categories) in the overall situation. This view of a 'potential for crisis' is NOT a deterministic concept but an optional one.

This article will thus, examine, firstly, the position of religion in a changed understanding of the term 'security'. In the past decade the term 'security' has been broadened from the contents point of view. This is of great importance because 'security' no longer covers only military issues but also demographical, political, economical, technological, ecological, religious and cultural issues. We are faced with a multi-layered network of triggers which have led to a complex situation of social change. Religion plays an important role in this context. As several definitions exist, a clarification of the term is necessary. This will support our understanding about the conditions under which religion may become a potential for crisis.

Secondly, the specific position of Islam will be analysed. Islam has a special position in this context because it covers all aspects of daily life in a strong, prescribing and determining way. Islam is both a political ideology and a religion at the same time. This part will, therefore, clarify the concept, define the prerequisites for the revival of Islam, compare the so-called 'Western System' and the 'Islamic System', and analyse the misperceptions on both sides and the resulting historical burdens.

This part should help us to understand why the two main streams will never converge but will have to accommodate each others differences. Moreover, it intends to show why Islamic movements, especially their offsprings in Western Europe, are perceived by many Westerners as a threat and as a potential for crisis.

As we are confronted with a complex problem, appropriate methods are necessary. Religious aspects amongst others are important in the network of security. A multi-disciplinary, systemic 
approach with a focus on historical sociology will be used to obtain an initial result.

\section{Times of Turbulence, Social Change and Change in Understanding of Security: New Aspects, New Challenges}

\section{The global system still under change}

A time of turbulence is a dangerous time, but its greatest danger is a temptation to deny reality. The new realities fit neither the assumptions of the left nor those of the right. They do not mesh at all with 'what everybody knows'. They differ even more from what everybody, regardless of political persuasion, still believes reality to be. 'What is' totally differs from what right and left believes 'ought to be'. The greatest and most dangerous turbulence today results from the collision between the delusions of the decision makers ... and the realities. But a time of turbulence is also one of great opportunity for those who can understand, accept, and exploit the new realities. ${ }^{1}$

The period after the break-down of communism is often called the 'new realities'. ${ }^{2}$ Old patterns of order have vanished and new patterns are still developing. In these 'new realities', new challenges arose and a new understanding of 'security' was required. Military issues which had been equated with 'security' for decades have become one of many issues. Although the understanding differs in detail, we assume that the areas of demography, politics (in a very broad understanding), technology, ecology, military and economy constitute meta categories which also cover much 'comprehensive' or 'extended' understanding of the term 'security'. 3

${ }^{1}$ P. Drucker, The Age of Discontinuity: Guidelines to Our Changing Society, reprinted edition, New York, 1992, p. 6.

${ }^{2}$ P. Drucker, The New Realities, in Government and Politics, in Economy and Business, in Society and World View, New York, 1989.

${ }^{3}$ A. K. Riemer, 'The Systemic-Evolutionary Extended Signal Approach: An Option to square the Circle of Early Warning?', Paper presented at the ISA Annual Meeting, Toronto 18-23 March 1997; A. K. Riemer, "The SystemicEvolutionary Extended Signal Approach: Theoretical Considerations and its Application in the area of Minority Issues', Paper presented at the Workshop, Synergy in Early Warning, University of York, Toronto, 15- 18 March 1997; A. K. Riemer, 'Religion as a potential for crisis? - The Case of Turkey', Paper presented at the Annual Meeting of ISSS 1997, Norfolk, Fall 1997. 
In this understanding religion is not a separate area but is placed under the category of 'politics', in the sense of creating and changing society. Religion and ethnonationalism are then often seen as 'new creative niches' for the solution of societal problems.

The most important issue is the fact of networking effects between the new potentials for crisis. It is not one issue or area which challenges the system, its structure and its agents, but it is the 'playing together' and the vice-versa-influence, which make an analysis and any following policy options difficult, if at times not impossible. With the change of the nature of the system and its contents, respectively the understanding of the term 'security' had to change as well although with a time lag.

From the point of view of a historical sociology, the changes that we have been facing in the last decade of the 20th century are not new. Going back in history we find several 'times of turbulence'. ${ }^{4}$ Comparing 1989/90 with the global situation hitherto, one can find certain special features marking it as 'distinct'. This period can be characterised as follows:

The global system itself faced a rapid change in the quality of structure, agents and interaction. The system's dynamics were far stronger than in the times of bipolarity. A multipolar system with a high level of complexity arose. Another phenomenon which became far more apparent than previous is the so-called 'simultaneity of the un-simultaneous'. This refers to the fact that we find number of similar events or developments on global level. On the regional and local level, however, there may be differences in time and quality of the development.

Religion has become a kind of 'bridge' for states and their societies finding themselves in a multidimensional pressure situation or in 'multidimensional times of turbulence'. Demographic changes such as population growth and population structure (with a high proportion of young people, i.e. until 25 years) provide the basic hotbed for radical religious movements. Moreover, domestic migration and consequent extended urbanisation have been developments which favour religious

4P. Drucker, Post-capitalist Society, New York, 1993. 
radicalism. Political conditions in which there is suppression of parties that favour the socially disadvantaged are seen as another trigger for radical religious movements. Economic conditions such as structural deficits and constantly negative economic framework data, especially sustained high unemployment rates for young people in urban areas, and social gaps likewise provide fertile grounds for the spread of religious movements. Under such conditions, they would have the opportunity to show how they can manage political activities and social engagement, e.g., hope and social acceptance are provided by them. In addition, technological underdevelopment is another issue which supports the rise and spread of religious movements. Furthermore, Selectively choosing parts from other dominating cultural systems and their selective adaptation have caused negative effects, thereby fuelling the chances for religious groups to rise.

In summing, up we can see that there have been a network of causes and conditions supporting religion in becoming a driving force in society and to be used for political purpose by religious movements.

\section{'Religion': A basic approach to find sense?}

The meaning of the term 'religion' is quite blurred. One finds several alternatives in literature to describe it. From a sociological point of view, religion is 'a kind of vehicle' to transform the undetermined world into a determined one. This especially refers to a society under transition. Niklas Luhmann, one of the leading German sociologists, promotes this approach. In his understanding religion has a bridging function, which absorbs disappointment caused by transition and societal change.

Another approach, promoted by Clifford Geertz, connects religion with the cultural system. Accordingly, religion is a system of symbols. It creates strong and permanent moods and motivations within people by formulating perceptions from reality. While the perception is a made-fact, consequent moods and motivations seem to correspond fully with reality. ${ }^{5}$ The system is

\footnotetext{
$5_{\mathrm{B}}$. Tibi, Der Islam und das Problem der kulturellen Bewältigung sozialen Wandels, 3rd ed., Frankfurt am Main, 1991, pp. 20-29.
} 
not evident in the sense of natural sciences but only by interpretation. Religion exists because there is faith and belief in a higher authority. In the case of monotheistic religions, God and the divine revelation are the authority.

On the other hand, reality is not something fixed but something which is permanently changing. When we assume that social change is actively brought about by people and not only reactively taken, religious ideas become concepts that have to be adapted as well. For this reason, most religions have, from time to time, endured periods of 'identity crisis'.

It is obvious that religious movements had and still have a strong impact on societal development. One could see this throughout the history. For a long time, knowledge per se was distributed by monks, for example through their monopoly on book printing. The freedom to chose religion in Europe was developed due to struggles between Catholics and Protestants. These are only few of the number of examples. In recent history, the foremost example is the role played by the Catholic and the Protestant churches during the break up of the Communist system in Poland, Hungary, the Czech Republic, Slovakia, and former Eastern Germany. On the other hand, we see the problematic role of religion in modern day Turkey. It has led to political and societal struggles between the grass-root politicians and the Army.

These struggles have covered several societal deficits and politicians' incapabilities to deal with a changed domestic, regional and global situation. Those few examples show the many sides of religion as an integral part of society. Thus, when we refer to 'religion' in this paper, a blend from the two concepts mentioned above is taken as an analytical tool. Consequently, in the following paragraphs, Islam is analyzed as a religious, political and societal concept.

\section{Islam: A Progressive Societal Concept or a Manifest Potential for Crisis?}

The role of Islam in society and politics has been one of the most discussed issues during the last thirty years both within the Islamic world and the international system at large. There is hardly 
any other topic even in international security discussions that has caused as much of a split among scholars of several disciplines and politicians. Several terror activities motivated by religious fundamentalism, have further fuelled the discussion.

Islam inspires fear and fascination in the Western imagination. It calls to mind puritanical holy warriors, fanatics, dervishes, suicide bombers, hijackers, and human waves thrown into battle. ... Political interest groups - the governments of Israel, Egypt, Algeria, Tunisia, and others wanting American support - propagandise about the Islamic danger. ${ }^{6}$

The key question which is still not answered is: Is Islam a progressive societal concept or does it represent a potential for crisis with global consequences? To be able to give a solid answer to this quite comprehensive question a clarification of the main contents of the concept and the prerequisites for its revival have to be investigated.

\section{Pax Islamica: Religion - Politics - Law - Guidelines for daily life}

When we try to answer the question, 'What is Islam?', we will find no single valid answer. 'Islam, like Christianity, is not a single doctrine with a single message, but a family of religious views. ${ }^{7}$ An orthodox Muslim would say: Islam consists of the Koran, the Hadith (authenticated traditions of Muhammad) plus the five pillars: 8 Schahada (confession to a divine unity and to Muhammad's prophecy), Salat (pray five times per day), Siyam (to fast rigorously during Ramadan), Zakat (alms), Hadj (pilgrimage to Mecca). Others may also be correct when they say, 'Islam is religion plus socio-political ideology. It is a basis to create identity and activity'. ${ }^{9}$ For a third group, 'Islam like other world religions is a faith of peace and social justice, commanding its adherents to

\footnotetext{
${ }^{6}$ I. M. Lapidus, 'A Sober Survey of the Islamic World', Orbis, Vol. 40 (3), Summer 1996, p. 391.

${ }^{7}$ Ibid., p. 392.

${ }^{8}$ Tibi, Der Islam, p. 30.

${ }^{9}$ R. Werle, Rennaissance des Islam - das Beispiel Türkei, Hamburg, 1987, p.16.
} 
worship God, to obey His laws, and to be socially responsible'. ${ }^{10}$ Although there are different definitions there is a common understanding in the Muslim world that those are the main ways to define Islam. But Islam is also a societal reality.

Islam is not that monolithic as it is often assumed at the first glance. ${ }^{11}$ This is one of the main incorrect assumptions about Islam particularly in the Western World. It biases reality and oversimplifies a very complex socio-political reality. Islamic reality varies structurally and culturally. First of all we can say that the term 'Islam' covers several lines, countries/regions and periods. Neither in reality nor dogmatically can a single and unified Islam be found.

From the very beginning of its existence Islam was assimilated by non-Arab tribes and peoples and was de-Arabised. Today an orthodox Arabian Islam and a number of non-Arabian variations exist. They differ in key issues. The reasons for differences are found in the different environment, the periods of time and the different doctrines within Islam. After Mohammed's death a struggle for the 'right doctrine in Islam' started. The two biggest groups have been the Shiites and the Sunnis. They are the result of a confessional splitting. Nevertheless, they have several features in common creating a fecling for community. This special feeling is not easily understandable for Westerners. ${ }^{12}$ The reason for this divergence is rooted in the development of both types of society.

Which are the basics for Islam? Koran (qur'an - recitation) is the key source. It covers religious aspects, the daily life, politics and legal matters. Koran has an unquestioned character. The texts represent the absolute authority for all activities of a Muslim. ${ }^{13}$ Under the aspect of absolute authority, change in society is not part

${ }^{10}$ J. L. Esposito, 'Political Islam: Beyond the Green Menace', Current History, January 1994, p.19.

${ }^{11} \mathrm{~F}$. Halliday, Islam and the Myth of Confrontation: Religion and Politics and the Middle East, London, 1995, p. 116.

12 Tibi, Der Islam, pp. 47-49.

${ }^{13}$ As'ad AbuKhalil, 'The Incoherence of Islamic Fundamentalism: Arab Islamic Thought at the End of the 20th Century', The Middle East Journal, Vol. 48 (4), Autumn 1994, p. 683. 
of the game. The norms are absolute and constant. Apart from absolute authority, Islam shows another facet deviating from other religions. Islam is an indivisible religion. The spiritual and secular levels are built upon a network. The most important message of the Koran is that the God and only the God is lawmaker. ${ }^{14}$ The key phrase is 'No governance except that of God'. ${ }^{15}$ This expression can be seen as an explanation for the very distanced relationship of Muslims towards governments and ruling authorities in the western understanding. ${ }^{16}$ Basically, all areas of life are influenced by those 'laws'. A separation of daily life and religion is not possible. In consequence a non-separable connection between politics and religion is 'natural'.

Another non-separable connection exists between legal regulations and religion. Every Muslim is an integral part of the 'umma' (community of brothers in faith), which is a kind of 'parenthesis' for all Muslims. It is widely accepted that Islam represents a universalistic approach which does not recognise racial, ethnic, or other differences among Muslims. The only criterion for membership is adherence to Islam. All Muslims, therefore, form a singly community called umma. Originally, it was hoped that the umma concept would act collectively to enforce order and overcome the basic tribal structure existed then within the so-called Muslim world.

This approach is not congruent with the modem nation-state approach and the international system based on it. This is not a surprise firstly, because the main idea was to find a vehicle going beyond the usual tribes and clans. A conscious delegitimisation of ethnic units was not necessary because it did not exist. And secondly, because at the time of revelation of Islam, the concept of nation-state did not exist as it is currently understood. Moreover, there are big differences in the interpretation of the Koran and the other sources, like Sunna, about the concept of umma, which is not bound to states in a political sense and keeps all Muslims across the world together. Islam covers estimated 1,2 billion people in 46

\footnotetext{
${ }^{14} \mathrm{~S}$. Al Ashmawy, 'Islamic Law and Human Rights', Foreign Press Association, pp.19-22.

15 AbuKhalil, The Incoherence of Islamic Fundamentalism, p. 679.

${ }^{16} \mathrm{~S}$. T. Hunter, The Future of Islam and the West, Westport, London, 1998, pp. 35-37.
} 
countries, including the successor countries of the former Soviet Union with a majority of Muslim population.

The Koran accepts the existence of other peoples but it points out the specific role of the Arabs. The Arab language is the leading language of Islam and the Koran. Islam is seen as one of the highly advanced civilisations in the world's history. It came into being in a socially and economically well developed city, in Mecca. Islam was a kind of a parenthesis for a number of rivalling tribes and clans which lived in the Arab Peninsula. It was and still is considered as an Arab monotheism although it claimed from the very beginning a universal desire for recognition. As it is not only restricted to nationality or ethnic group, Islam had the opportunity to spread across the world. Thus, Islam has not focused only on the Arab populated lands, though this area was its birthplace. ${ }^{17}$

This overview on the basics of Islam shows the indivisibility of the concept as a broad multifunctional approach to design society as well as its latent or manifest contradictions.

\section{Political Islam - pleonasm or societal reality?}

As described and analysed above, Islam covers all aspects of life. This means that politics is included as well. ${ }^{18}$ This aspect of the Islam, that is the convergence of politics and the religion has been one of the most discussed issues in western society. The basic question concerning the connection between Islam and politics is whether a theocracy can ever be a democracy. ${ }^{19}$ The political story of the modern Islamic Orient is characterised by a change of religious and secular ideologies. ${ }^{20}$ As previously mentioned, Islam is a non-discussible guideline for all activities of daily life as well as

${ }^{17}$ B. Tibi, Die Krise des modernen Islams, 2nd ed., Frankfurt am Main, 1991; Tibi, Der Islam, pp. 30-46.

${ }^{18}$ I. A. Karawan, The Islamist Impasse, Adelphi Paper 314, Oxford, New York, 1997, pp. 20-24.

19 A. A. Mazrui, 'Islamic and Western Values', Foreign Affairs, September/October 1997, p. 124; B. Lewis, Islam and the West, New York, 1993, pp. 4-5; B. Lewis, The Shaping of the Modern Middle East, rev. ed., New York, 1994, pp. 54-56.

${ }^{20}$ Esposito, Political Islam, pp. 19-24. 
for political decision making and for legal affairs. Therefore, the usage of the term 'political Islam' assumes a degree of tautology. When the term 'political Islam' is used, there is usually no connection to societal politics - although the Koran and Sunna would provide adequate guidelines. This is one of the big mistakes or misperceptions in the western society, simply because of a different understanding of politics in the Islamic World and a century of clear separation between religion and politics ('laicism') in the Western World.

In the Muslim interpretation, 'Political Islam' very often refers to a catch phrase like 'turn the times back to the golden age of Islam'. Simply the step back to Islam is assumed to solve all societal problems. The basic line under discussion is 'anything goes - no details only the mainstream which is just Islam'. Because of the absolute status and the indivisibility of Islam, reality has to adapt to Islam and not the other way around. One of the key features of the revival of 'Political Islam' is a reinterpretation of Islamic and religious values to a politically based doctrine. ${ }^{21}$ The key target is to establish an 'Islamic Order' (Nizâm-1 Islamî) on the national and international level. This is a very interesting interpretation, simply because it has a contradiction inherent as the usage of the term 'nation' has been refused and not accepted by Muslims since centuries. Nizâm-ı Islamî is intended to replace the existing but refused order organized according to Western examples. In this sense, 'Political Islam' does not provide future perspectives but gives a past-based vision of the future. In this make-believe future, the past has to be re-constructed as well. As present and future are not really relevant in this interpretation, it could be argued that 'Political Islam' is a backward orientated interpretation of Islam.

The reasons for the Islamic revival are presented as follows. ${ }^{22}$ Secular nationalism was not successful in the Muslim countries. The governments in Muslim countries were unable to establish political legitimacy. ${ }^{23}$ They were repressive and did not show a high level of responsibility. Moreover they were often run by small cliques of insiders or elite tribes with a century of history

${ }^{21}$ Karawan, The Islamist Impasse, pp. 20-24.

${ }^{22}$ Esposito, Political Islam, pp. 20-21.

23 A. R. Norton, 'The Challenge of Inclusion in the Middle East', Current History, January 1995 , p. 2 
that legitimated them. Only a handful of people could benefit. The majority of people have hated the governments. Political (for being too pro-western) and religious establishments (for cooperating with governments) came under heavy critique. Social structures 'catching' the poor and less educated faded away because of urbanisation pressure. Moral collapse due to extreme consumption and a materialistic life-style led to a crisis in meaning. A societal scissors movement provided the fertile ground for Islamic movements, radical or not. Consequently, especially from the late 1960s onwards, Islamism has been seen as a third alternative to communism and capitalism.

The movements of 'Political Islam' are based in cities and recruit their clientele from the lower and middle classes. Many of the followers have obtained a university degree and/or are well fixed in their jobs. The locations for recruitment are campuses and mosques. The discipline-background goes into medicine, science, engineering, education and law but less in the religious faculties which might be surprising at the first glance. Islamic movements are strictly organised. Their sub-organisations cover all aspects of daily and social life. Social activism and an increased political participation took place in parallel. Therefore re-politisation of the sacred in the Islamic Orient is a better description for the phenomenon that we always call re-islamisation or 'Political Islam'. ${ }^{24}$

\section{Radical Islam, Islamic Fundamentalism, Islamic Revivalism: A new perspective?}

Whereas Islam has existed for 1,300 years, Radical Islam or Islamic Fundamentalism or Islamic revivalism (those terms are often used synonymously) arose during the 1970s. ${ }^{25}$

${ }^{24} \mathrm{~B}$. Tibi, Die fundamentalistische Herausforderung. Der Islam und die Weltpolitik, München, 1992, p. 45.

${ }^{25}$ The term 'fundamentalism' is used in many ways. 1)All those who call for a 'back to the roots', to the fundamentals of a religion, 2) All those who replicate the past and wish to return to it; and 3) Fundamentalism is equated with political activism, terrorism, fanaticism. Since the term recently ha become laden with Christian presuppositions and Western stereotypes, Esposito suggests the terms 'Islamic revivalism' or 'Islamic activism', and states that in recent years terms such as 'political Islam' and Islamism' have 
Two questions and their subsequent answers will help us to understand this phenomenon.

First we have to clear the question 'What does Islamic revivalism mean?' Islamic revivalism is a stream of Islam that is very much ideologically underpinned. Moreover it is a social and political phenomenon. Finally, it is seen as part of the globalisation and in a sense its consequence. ${ }^{26}$ This development is not restricted to Islam, but it is a new issue within Islam. Islamic revivalism does not necessarily have to show a violent dimension. However, as many of the groups or their leaders are banned from political participation, violence often becomes the only possibility to attract the attention of the world public. Three of the most influential movements (Justice and Charity in Morocco; An-NahdahRenaissance in Tunisia; and Islamic Salvation Front in Algeria) were basically moderate in their political dimension and became more violent in the past years because they were suppressed by their governments. ${ }^{27}$

The values which are promoted by political Islamists are not traditions but interpretations of traditions. This makes the movements so dangerous because they have become self-dynamic. Therefore fundamentalism is neither traditionalism nor modernism, but the 'dream of a half modern age'. ${ }^{28}$ Islamic revivalism is characterised by a defensive and culture-targeting pathos with idealistic visions. It does not provide the necessary strategy to overcome the problems induced by the rapid social change during the 20th century. Islamic revivalism claims the absolute superiority of Islam towards all other existing ideologies, that peace in the world can be brought with the dominance of Islam ('al-taghallub'),

become common language. See J. Esposito, The Islamic Threat, New York, Oxford, 1999, p. 6. In this paper, the term 'Islamic revivalism' is used because in our understanding it describes the connection between religion and ideology best.

${ }^{26} \mathrm{~B}$. Tibi, Islamischer Fundamentalismus, moderne Wissenschaft und Technologie, 2nd ed. Frankfurt am Main, 1993, p. 49.

27 J. P. Entelis, 'Political Islam in Algeria: The Nonviolent Deminsion', Current History, January 1995, pp.13-17; J. Miller, 'Faces of Fundamentalism. Hassan al-Turabi and Muhammed Fadlallh', Foreign Affairs, November/December 1994, pp. 123-142.

${ }^{28}$ Tibi, Die fundamentalistische Herausforderung, p. 52. 
the monopoly of truth (not discourse but suppression is the line), the possession of the unchangeable, absolute and divine message, the monopoly of preaching the message to the whole of mankind without any compromise and the only faith as a clearing position for interaction and communication. Islamic revivalism, which targets at establishing Nizâm-ı Islamî, does not have any concrete idea for realising this ordering concept. The leading idea is to destroy the current system of power, because it is secular and not religious. The gap between idealistic visions and the harsh, sometimes brutal societal reality creates a high potential for crisis. Summarising the answer to the first question about the contents of Islamic revivalism, it could be argued that it is a romantic but dangerous protest movement. ${ }^{29}$

The second question is: Why could Islamic revivalism come into existence? The answer is to be found in the so-called 'unmastered simultaneity of unsimultaneous streams' in society. The simultaneity of Islamic universalism and the secularised order of nation states, the tension between 'openness for change' and 'resistance to change in their own views and standpoints' represent scissors movements. Islamic revivalism is a multidimensional and interlocked reaction to a far reaching disappointments.

First, it is an answer to a generally negative attitude to the socalled 'modern Western society system'. Secondly, it is an answer to the lack of visions and ideals provided by the Western system for the Islamic society, and to the unmastered rapid societal change, which stands in a sharp contrast to the absolute, universal, unchangeable and authoritative Islam. Thirdly, it is a rebuttal of the superficial outcry of the European/Western world order, which is seen as the source for the present dilemma. Fourth, it is seen as a reaction to the underdevelopment resulting in many societal problems. Fifth, it is an opposition to the externally induced change in society which is perceived as the threat by alien powers. And finally, it represents the fears of social change and a future which is not determinable, and the failure of the concept of nation state in Islamic countries.

It should be mentioned here that Islamic revivalism is not a homogeneous movement. It covers a number of groups with local

${ }^{29}$ Ibid., p. 161. 
leaders. This heterogeneity is seen as the main obstacle to become a politically influential power. On the other hand, fragmentation and diversification have made control impossible and future perspectives do not look very promising.

Summarising the results on the analysis of what Islamic revivalism is and why it did come into being, the following can be deduced from the foregoring discussion:

Islamic revivalism is a dangerous but romantic protest movement, which has come into existence because of a multifaceted disappointment of the Islamic societies and their governments' incapability to deal with a globally changed situation.

\section{Islam and the West: A Never Ending Story of Misunderstanding and Non-acceptance}

Are Islam and the West on an inevitable collision course? Are Islamic fundamentalists medieval fanatics? Are Islam and democracy incompatible? Is Islamic fundamentalism a threat to stability in the Muslim world and to American interests in the region? These are critical questions for our times that come from a history too often marked by mutual distrust and conflict. 30

Although Islam and Christendom have a number of common theological roots and beliefs, the relationship has been overshadowed by conflict. Armies and missionaries have often fought for souls and for power. The search for a 'new world order' is not a new phenomenon. Both the Western World and the Islamic community have been trying to implement their world order for centuries (when I speak of 'world order', I refer not only to politics but to a network of politics, economics, culture and religion). Defeats and victories show a very changing pattern in an even more changing relationship between two of the main religions. The two 'worlds' may be characterised as an example for dichotomy: tradition versus change, fundamentalism versus modernism, stagnation versus progress and development. ${ }^{31}$

${ }^{30}$ Esposito, The Islamic Threat, p. 1.

${ }^{31}$ Ibid., p. 7. 
The current basic problem in connection to the ideological differences is a multi-layered and complex situation. It is characterised by the search for a 'new world order', by modern cultural movements and the simultaneity of structural globalisation and cultural fragmentation. The inherent politicisation of Islam and the conflict between Western and Islamic civilisations stand in tight and direct relation. The tension has existed for 1,300 years. History is full of examples of the permanently difficult relationship. ${ }^{32}$

Colonisation by the European states was the first challenge for the Islamic world. This phase is seen to be finished. The second challenge has been the era of modernisation. This process of adaptation is still ongoing for Islamic countries. Many Muslim leaders are fighting to 'get back to the roots'. Western influence has been connected with technological, military, economic and scientific superiority. Therefore it has to be controlled, and if possible, partially banned. ${ }^{33}$ The Western world pushed for a separation of state and religion, which was necessary to solve the question of modernisation. ${ }^{34}$ The Age of Enlightenment and its far reaching idea and ideals has been seen as the key element in this 'separation process'. One can claim that this process was completed decades ago. Nowadays no one really questions secularism in the Western countries.

Islam did not bring enlightenment or revolution. The 'corset of absolute truth' has been a 'corset' in a very negative sense. Deviations from the line of Islam have been banned and fought against. On the other hand, very free and individual interpretations of the basic sources have been carried out, thereby leading in some cases to a distortion of the intended contents.

${ }^{32}$ S. Huntington, 'The Clash of Civilizations?', Foreign Affairs, Summer 1993, pp. 31-32; Hunter, The Future of Islam and the West, pp. 11-17; Esposito, ibid., pp. 1-4.

$33 \mathrm{~J}$. Rovan, 'Der fundamentalistische Islamismus bedroht Europa', Internationale Politik, 2/1995, pp. 47-52; R. W. Bulliet, "The Future of the Islamic Movement', Foreign Affairs, November/December 1993, pp. 38-44.

${ }^{34}$ Literature does not provide a single definition of the term 'secularism' or its French rooted pendant 'laicism'. In this paper, I go according to the most used understanding of a strict separation between state and religion. Religion is seen as a private matter and does not affect state's affairs like the legal structure and education. 


\section{Islam and the Western World: A short comparison}

When we speak of a kind of 'crash of ideologies' between the Western system and Islam, we usually refer to the divergent positions and views between the Pax-Americana and the PaxIslamica, and the so-called 'simultaneity of structural globalisation and cultural fragmentation'.

In the following, a brief overview of the core contents of Pax Americana and Nizâm-ı Islamî will be given, both concepts will be compared and an interpretation of the so-called simultaneity of structural globalisation and cultural fragmentation will be provided.

\section{Pax-Americana versus Nizâm-ı Islamî/Pax Islamica}

Pax-Americana is used here as a synonym for the Western society. It has its roots in European history. The Westphalian Peace Agreement (1648) marked the end of the then dissolving sacred order and the beginning of a modern, secular and international system of nations/states. The cultural framework for this development has been provided by the 'Modern Age'. ${ }^{35}$ When we speak of 'Modern Age', we refer collectively to individualism, the right for critique, the autonomy in action and a reflexive faith (man is the oneself knowing idea). These elements have been valid and benchmarks for all societal claims in the Western world until today.

On the other hand, we have to analyse Nizâm-l Islamî as expression for the societal concept in Islam. It stands in close connection with the expansion of Islam and the incompatibility of the umma concept to cope with a community of a high number of tribes going beyond the Arab borders.

35 According to Habermas, the 'Modern European Age' is a combination of culture, technology and science in a very specific way. For its characteristic features, see Tibi, Die fundamentalistische Herausforderung, pp. 50-51; F. Mernissi, Islam and Democracy: Fear of the Modern World (trans. M. J. Lakeland), Reading, MA, 1992, p. 42; B. Lewis, 'The West and the Middle East', Foreign Affairs, Vol. 76 (1), January/February 1997, pp. 114-130. 
'This vast community could no longer be governed and administered solely according to the tribal traditions of Arabia, especially since many of the peoples conquered by Arab Muslim armies had advanced civilisations and longer experience in governing and administering extensive empires than the Arabs. To govern their new conquests, the Muslims thus had to build their states and develop their governments. ... A great deal of this had to be borrowed from civilisations that the Muslims considered as belonging to the era of darkness, ignorance, and corruption...36

Muslims were, due to expansion of the Western state system and its superstructure, confronted with the inherently parochial concept of nation-state and tried to 'blend' it with the universalistic concept of Islam. A political and institutional concept (nationstate) has to be brought in the umma approach, which 'by nature' is political as well as the spiritual and social expression of Islam. It has been a de facto effort to 'bridge the unbridgeable', to melt two incompatible societal concepts.

The concept of Nizâm-l Islamî has never accepted history, existing political structures or institutions. Thus, in a sense, we can even speak of a 'denial of history', simply because of Islam's claim for absoluteness and its fixed and unchangeable character. If correspondence with Islam was and is missing and a deviation from the Koran was and is existing, this was and still is not accepted. One also has to take into account that the benchmark for this assessment in Islamic societies has never been the Koran but the interpretation of it. However, this issue has very often denied by Islamists and not usually noticed by Westerners. In reality, however, those reinterpretations and misinterpretations make the whole issue extremely difficult to understand.

Nizâm- $ı$ Islamî although a very vague and contradicting concept - is seen by many political Islamists as a means to solve political, economic and social problems which evidently exist in the Muslim countries. Religious aspects are NOT the thriving force for establishing Nizâm-l Islamî. It is often assessed as an answer to a crisis in meaning in the Islamic system itself. Islamists and promoters of Nizâm-l Islamî. see this 'concept' as the answer of a

${ }^{36}$ Hunter, The Future of Islam and the West, p. 41. 
pre-industrial culture in a rational, secular, technological and scientific age. ${ }^{37}$

Nizâm-ı Islamî requires Islamic legitimacy. Umma as the community of brothers in faith has to underpin this legitimacy and the political power to keep the Nizâm-l Islamî. As a first step, the Nizâm-ı Islamî has to be established on a 'national level', which is another contradiction in itself as nations in the Western sense of the term do not exist in the Islamic system. After a certain period of time, which is not defined in advance, the 'tools of globalisation' (again without definition to keep the 'selective gap' open) will be used to make the ideas and ideology applicable to the world's level. Here we have another contradiction. Nizâm-Islamî is another expression for contradiction and selective choice.

Summarising the key issues concerning Nizâm-Islamî, we can say that disorientation, a structural and a meanings crisis are the ingredients fuelling Nizâm-Islamî, which is a blurred concept. Religious values are re-interpreted in a political doctrine to solve a multidimensional intra-system crisis caused by internal and external factors. The target is to establish an 'Islamic System' on the national and international level instead of the secular one, even if this is a contradiction to the original intention of Islam and its basics.

To come to a comparative approach we have to find out the key differences between Pax-Americana and Pax-Islamica. I picked out three non-solvable components of each system to demonstrate the ir-reconcilability:

\section{Subjectivity versus Collectivity \\ 2. Nation State versus Umma \\ 3. Universality versus Universalism}

First, we analyse the position of the individual or try to answer the difference between the principle of subjectivity versus the one of collectivity. The principle of subjectivity is a result of the Age of Enlightenment. It stands in close connection to individual human rights and is in sharp contrast to the one of

${ }^{37}$ Tibi, Die fundamentalistische Herausforderung, p. 86. 
collectivity. Collectivity is represented by the umma. The individual does not count in Islam as it does in Western societies. This is in turn reflected in the problem of accepting the concept of nation, which is, in the Islamic understanding more a 'selected nice concept to have but not a must'.

Second, nation state versus umma is another big difference which reflects the previously mentioned issue on a higher organisational level. The nation state is a key element of European History. ${ }^{38}$ On the other hand, Islamic countries have had the impression that they have been forced to use the nation state concept through colonisation. The Muslim world was not a closed area anymore although Muslims of today see themselves as an exclusive part of the world. The concept of nation state was a manifold innovation for the Muslim countries. First of all, the concept is based on inner sovereignty. This covers features like citizenship, national identity and loyalty. The second part is the existence of external sovereignty, which refers to a mutual acceptance of territorial integrity and non-interference in the domestic affairs of the other states. Tribal structures in the preIslamic Arab societies stood in sharp opposition to the nation state. Tribalism has not been overcome so far, especially within the Arab world, not even by the umma concept. Moreover, the clan spirit has been modernised but not substituted by the nation state. ${ }^{39}$ On the contrary, it may be argued that this approach has fuelled it. In this context, the decay of the Ottoman Empire is considered as the end of a sacred order. ${ }^{40}$ After 1924 (end of the Caliphate) the Arab countries tried to implement the 'nation's idea' to their countries. What they had in their minds was not a region of artificial Arab countries but one of a 'big Arab nation within the existing international system of nations'. It is the idea of 'Pan Arabism' or the one of a 'universal Caliphate'. The term 'nation' became a new element. The application of the concept of nation to the Arab countries stood in sharp contrast to the universalism of Islam. After the Six-Days War in 1967, the secular pan-Arab nationalism was substituted by the 'Political Islam'. From then onwards, the concept

${ }^{38}$ Ibid., p. 71.

${ }^{39}$ B. Tibi, Vom Gottesstaat zum Nationalstaat. Islam und panarabischer Nationalismus, 2nd ed., Frankfurt am Main, 1991, pp.15- 24.

${ }^{40}$ G. Kepel, 'Der lange Marsch der Islamisten', Europa-Archiv, Folge 3/1992, pp. 71-75. 
of a world-wide community of Muslims called umma was dominating. ${ }^{41}$ The secular concept did not produce the expected result and was, in consequence, assessed as inadequate. On the other hand, the umma concept targeting at a 'world embracing community' does not take the classical concept of nation into account. 'One all-embracing concept for all Muslims' has been the catch phrase.

The third big difference is universality versus universalism. Universality is primarily a Western philosophical principle that accepts a variety of ideas, religions and ideology in a society. Several approaches are possible and acceptable. Universalism on the other hand is the leading principle in Islam (but not only in this religion - Communism has the same basic assumption of a universality principle), which accepts only one model for the whole society. It is generally valid and refers to the whole mankind.

\section{Simultaneity of structural globalisation and cultural fragmentation}

Globalisation is one of the buzz words at the end of the 20th century. It is 'a label that is presently in vogue to account for peoples, activities, norms, ideas, goods, services, and currencies that are decreasingly confined to a particular geographic space and its local and established practices'. ${ }^{42}$ Although we do not have a common definition of 'globalisation', we have something like an unspoken image of features for this phenomenon. When we speak of globalisation, we mean unifying structures, certain conditions, a final state and a process covering a large part of the world. Basics in societal structures show a common world-wide level. Similarly, we face an obviously contrasting and even contradicting societal trend. It is summarised with the term 'cultural fragmentation'. People who are from a structural point of view quite close together, differ drastically in their cultural perception. Cultural fragmentation is seen as the driving factor for the creation of the need for common values, guidelines and rules. They are the

\footnotetext{
${ }^{41}$ M. A. Faksh, "The prospects of Islamic fundamentalism in the post-Gulf War period', International Journal, Spring 1994, p. 184.

42 J. N. Rosenau,'The Dynamics of Globalization: Toward an Operational Formulation', Security Dialogue, 1996, Vol. 27 (3), p. 247.
} 
cement for a working international system. Culture can be such a cement. But, cultures are local phenomena, and a universal culture does not exist. World orders like the Pax-Americana or the PaxIslamica are only two of several possible options for a restricted area. They do not represent the philosopher's stone. On the other hand, it is obvious that fundamentalism and re-politisation are two key consequences of these overlaying and controversial developments. ${ }^{43}$

Ending up this small comparative analysis, one finds out that Islam tried to adapt 'Western issues' in a selective way and has failed so far. This 'half modern ages approach' has brought the Islamic countries into manifold difficulties. Intra-societal discussions and disputes are over-layered by inter-societal clashes. ${ }^{44}$ This is not the way for mutual understanding and acceptance, which seems to be a long and winding road.

\section{Conclusion and Outlook}

Fear often issues in the demonization of an enemy or threat. For decades, international relations were conducted within the context of a superpower rivalry, between East and West, the Soviet Union and the United States. In the post-Cold War period, many who seek new demons warn of an Islamic threat to Western civilization or of an impending clash of civilizations. ${ }^{45}$

The main target of this article was to answer the question whether a religious concept which is strongly politicised like Islam can be potential for crisis.

We found out that the fusion of politics and religion is not a phenomenon which is found only in connection with Islam; this fusion per se does not present a potential for crisis (Christendom has represented a main power in western politics for centuries); it is the misinterpretation and the misuse of religion in the name of politics that represent a potential for crisis (this was apparent centuries ago during the crusades); that it is due to system inherent

${ }^{43}$ Tibi, Die fundamentalistische Herausforderung, pp. 20-23.

${ }^{44}$ Esposito, The Islamic Threat, pp. 212-289.

45 Ibid., p. 212. 
facets that Islam as a religious concept provides a more fertile ground for politicising and making a dual use of it than in the case of other concepts; it was in a considerable number of cases the change in several Muslim states and the massive western intrusion that lead to a drastic loss in independence and a shift in power and influence in favour of the West, and the following Muslim efforts to rebalance power were in many cases not very successful; religious parties have always replied to weaknesses in society and made political use of it. Consequently, political Islam has become a cultural and societal phenomenon; due to the separation of religion and state '(laicism'), the risk of religious groups' engagement in societal issues and gaps opened by politicians in the western world is smaller than in the Islamic world, but it still exists even though it is often denied; the 'half-hearted modernisation' and the 'selective adaptation' in many of the Muslim countries resulted in more damage than benefit for them; the resulting defeats and the above mentioned societal deficits have led to a revival of Islam.

Providing an outlook one has to be aware which is the cause and which is the effect in the societal development. It is the overlayered situation of the manifestation of social, economic and political discontent in societies, which are in many cases still not recognised as driving forces for a flight into religious movements. Knowledge deficits lead to myths and undefined fears. After the revolution in Iran and the negative western experience with this phenomenon, a new 'enemy' - Political Islam - was born. This development was fuelled after the decay of the Soviet Union. The 'old evil' was lost, a new one had to be found. Radical Islam offered a nice opportunity.

All participants in this 'societal game' still have not learned their lessons. For this reason religious movements like different Islamic groups will go on playing an important role, not only in their own culture but also in other cultures and will make use of several potentials for crisis finally to become a potential for crisis of their own. 